\title{
The ideological origins of the Population Association of America
}

\author{
Dennis Hodgson \\ Fairfield University, hodgson@fairfield.edu
}

Follow this and additional works at: https://digitalcommons.fairfield.edu/sociologyandanthropologyfacultypubs

Archived with permission from the copyright holder.

Copyright 1991 Wiley and Population Council.

Link to the journal homepage: (http://wileyonlinelibrary.com/journal/padr)

\section{Peer Reviewed}

\section{Repository Citation}

Hodgson, Dennis, "The ideological origins of the Population Association of America" (1991). Sociology \& Anthropology Faculty Publications. 32.

https://digitalcommons.fairfield.edu/sociologyandanthropology-facultypubs/32

\section{Published Citation}

Hodgson, Dennis. "The ideological origins of the Population Association of America." Population and Development Review 17, no. 1 (March 1991): 1-34.

This item has been accepted for inclusion in DigitalCommons@Fairfield by an authorized administrator of DigitalCommons@Fairfield. It is brought to you by DigitalCommons@Fairfield with permission from the rightsholder(s) and is protected by copyright and/or related rights. You are free to use this item in any way that is permitted by the copyright and related rights legislation that applies to your use. For other uses, you need to obtain permission from the rights-holder(s) directly, unless additional rights are indicated by a Creative Commons license in the record and/or on the work itself. For more information, please contact digitalcommons@fairfield.edu. 


\title{
The Ideological Origins of the Population Association of America
}

\author{
DENNIS HODGSON
}

THE FIELD OF POPULATION in the United States early in this century was quite diffuse. There were no academic programs producing certified demographers, no body of theory and methods that all agreed constituted the field, no consensus on which population problems posed the most serious threat to the nation or human welfare more generally. Individuals considering themselves population specialists included biologists, public health officials, geographers, historians, sociologists, economists, statisticians, lawyers, political activists, and politicians. They were concerned about overpopulation, depopulation, uncontrolled fertility, excessively controlled fertility, unrestricted immigration, race suicide, and race degradation. When examining a field with such porous boundaries, several approaches can be used. One can use the firm boundaries that eventually came to demarcate demography, and treat only those works that would presently be viewed as authentically "demographic." A clean, but sparse, history of the academic discipline would be the result. Alternatively, one can accept the fluidity of the field as it existed, and treat all that then was thought to be population-related. A rich, but chaotic, history of population thought would be the result. The second approach is taken in this essay.

This approach promises to shed a different light on the field of population studies from that which would come from a disciplinary history. During the early decades of this century population change provoked more action than analytic advance, more tracts on population problems than methodological treatises. Legislative initiatives aimed at solving assorted population problems distinguished the era: thousands of feebleminded individuals were subjected to eugenic sterilization by law, quotas were passed that restricted entry of southern and eastern Europeans into the United States, laws were challenged and women gained greater control of their reproductive 
processes. Although many of the beliefs about race, class, and gender held by early students of population might repel today's demographer, as might their penchant for proselytizing, much can be gained from examining their work. The ideologies that stirred them arose in a particular historical context and affected the thinking of most educated Americans. The interest in population matters stimulated by these ideologies helped to establish the discipline in America. Examining population thought in an era of ideological discord also highlights an aspect of the field often overlooked today: concern about population arises as much from value considerations as from demographic trends.

The major problem of the inclusive approach taken here is determining a contemporarily correct definition of the field. Fortunately, a document exists that helps resolve this problem for early twentieth-century America. In December 1930, 13 people "immediately concerned with research and work in the field of population" met in the New York University office of Henry Pratt Fairchild, professor of sociology and advocate of immigration restriction. They were planning the formation of the Population Association of America (PAA). Margaret Sanger, who had procured funds for the endeavor, was there along with Eleanor Jones, president of the American Birth Control League. Harry Laughlin had come in from the Eugenics Record Office on Long Island, and Louis Dublin and Alfred Lotka had traveled downtown from the actuarial offices of the Metropolitan Life Insurance Company. O. E. Baker, a geographer at the Department of Agriculture, was up from Washington, D.C. Lowell Reed, population biologist from Johns Hopkins University, and P. K. Whelpton, agricultural economist from the Scripps Foundation for Research in Population Problems, rounded out the academic contingent. Representatives from several foundations were also present. A tentative constitution was drafted and a list of some 70 names drawn up. These would receive letters inviting them to a "Second Conference" in May 1931 at which the Association would formally be established.

This list of invitees, probably more than any other document, delineates the various strands that constituted the field of population studies during the early decades of this century. ${ }^{1}$ In addition to Sanger and Jones, the birth control movement was represented by Robert Dickinson and Stuart Mudd. A full range of eugenicists was invited, from the unrestrained to the temperate: Guy Irving Burch, Clarence Campbell, Charles Davenport, Eugene Gosney, Samuel Holmes, Ellsworth Huntington, Frederick Osborn, Paul Popenoe, and Leon Whitney. Even though passage of the national origins quota acts had lessened the salience of their movement, immigration restrictionists were not forgotten. Albert Johnson, Chair of the House Committee on Immigration and Naturalization, and Robert DeCourcy Ward, one of the founders of the Immigration Restriction League, were on the list. Controversy was not avoided. Herbert Jennings and Raymond Pearl, authors of recent harsh cri- 
tiques of the eugenics movement, were invited, as was George Kosmak, conservative physician and critic of the birth control movement. Compilers and analyzers of demographic statistics-from government, industry, and academe-made up a core of invited population "scientists": Robert Chaddock (Columbia), Joseph Hill (Census Bureau), Robert Kuczynski (Brookings), Leon Truesdell (Census Bureau), P. K. Whelpton (Scripps), and Walter Willcox (Cornell). Overall, though, activists outnumbered scientists by a fair margin. Many of the academics invited were more noted for their advocacy than their objectivity: Edward East, Roswell Johnson, Clarence Little, and Edward Alsworth Ross.

This list reflects the field of population as it was during the decades preceding 1930, and reminds those interested in the history of the discipline that it is the offspring of mixed parentage and stormy unions. During these years population dynamics had become a central concern for a variety of movements, and activists inundated the field. Conflicts abounded. For the eugenicist the small family of the well-to-do was a national problem; for the birth controller it was a model for all other classes to follow. Each movement, with its distinctive population priority, competed for the public's acceptance. Population was a visibly controversial field. Only gradually did the advocates of various movements come to perceive their points of agreement as outweighing their points of dissension; a meeting such as that which took place in May 1931 is difficult to imagine occurring ten or 20 years earlier. This period of advocacy and controversy had its roots in the intellectual and demographic trends of the late nineteenth century.

\section{The seeds of controversy}

When Malthus wrote his Essay on Population he used America's 25-year doubling time to estimate the speed at which population can increase when faced with no resource limitations. America, with its immeasurable frontier, was the exception proving the Malthusian rule. With land abundant and "free," more hands were needed to tame it. In the early nineteenth century, American students of population were overwhelmingly optimistic about the country's capacity to absorb and employ additional people (Tucker, 1822; Carey, 1840: 47-52). Both population increase and territorial expansion were used to gauge the nation's progress.

One of the major demographic trends of the century, fertility decline among city dwellers and the well-to-do, was noticed quite early (Tucker, $1822: 315-318 ; 1843: 103)$. Malthus had thought that the middle and upper classes were more capable than the lower classes of exercising "moral restraint," delaying marriage and having only those children for whom they could adequately provide. George Tucker, likewise, attributed declining fertility in these groups to their "prudence" and "pride." As the century pro- 
gressed and fertility continued to decline, explanations pointed to a rising standard of living as the factor responsible. A growing portion of the population was enjoying an elevated standard of living and was acting in ways to protect it. The gloomy forecast of the mass of mankind living in poverty as population continually pressed against the means of subsistence gave way among American political economists to an optimistic vision of a rising standard of living serving to check any excessive fertility that might threaten it (Hutchinson, 1967: 317-318).

As the nineteenth century came to a close, though, America had ended its territorial expansion and was "filling up." Its increasingly urban and industrial character was hard to ignore as the 1880 census recorded a majority of the workforce engaged in nonagricultural pursuits. Students of population noted the passing of the frontier and heralded the coming of a labor problem. Richmond Mayo-Smith (1888b: 218-225) argued that with the best lands already under cultivation and with an industrial infrastructure largely built, there would be a declining demand for unskilled labor and more competition within the working class. Francis Walker (1892) held that the impact of immigration changed from positive to negative with the passing of the frontier. While land was not as dear and labor not as cheap as in the Old World, Malthusian assumptions came to dominate analyses of American demographic trends. ${ }^{2}$

Nearly a century had now passed since Malthus first published his essay, and intellectual developments greatly influenced its late nineteenthcentury American reimpression. Darwin had used Malthus's idea of excess reproduction fueling a fight for survival to develop an explanation of biological change. Spencer had presented an expansive evolutionary theory that encompassed both the biological and social realms, encapsulated in his expression "survival of the fittest." Belief in the power of competition and natural selection to produce beneficial change had become nearly universal (Hofstadter, 1945; Bannister, 1979). ${ }^{3}$ Racial theories positing "lower" and "higher" races also had come into vogue. John Fiske, first known for his extreme espousal of Spencerian and Darwinian thought, established the Teutonist historical school and popularized Anglo-Saxon racism in America (Solomon, 1956: 62). Teutonism, Anglo-Saxonism, and later Nordicism isolated the superior race in northwestern Europe. Such "scientific" racism found ready acceptance among educated Americans. Academics, who happened to be overwhelmingly of northwestern European heritage, found it especially enthralling.

The use of class position and race as surrogate measures of biological quality was commonplace. In this context the low fertility of middle- and upper-class "native" Americans, descendants of the preindependence white population that was largely of British extraction, became viewed as a problem, especially after 1880 when the immigration of eastern and southern Euro- 
peans increased dramatically. The less fit seemed to be replacing the more fit, and commentators began speaking of race degeneration, race degradation, and race suicide (Walker, 1891; Fetter, 1899; Ross, 1901). Walker (1891) linked fertility trends to immigration trends and produced an explanation of the native American small family that had a profound impact. He labeled (1896: 828) the "new" immigrants "beaten men from beaten races; representing the worst failures in the struggle for existence." Their willingness to work for low wages made native Americans despair for the future and "unwilling to bring sons and daughters into the world to enter into that competition." The vision of prolific and inferior immigrants supplanting quality Anglo-Saxon stock served as the intellectual foundation for the Immigration Restriction League, established in 1894. By arguing that the two "degenerative scourges" threatening the American population were causally linked, Walker's theory served as a bridge connecting the nativist and eugenics movements.

A new Malthusianism arose, then, among many late nineteenth-century students of population that differed from the classic sort. The vision of a "filled" America facing resource limitations did not produce simple calls to slow population growth. The addition of racist and Darwinian ideas heightened compositional concerns. Immigrants of "inferior" races and those possessing defects of character, intellect, or physique had to be excluded. The high birth rate of the lower classes, especially of recent arrivals whose stock was of questionable value, was cause for concern, but so was the low birth rate of the native middle and upper classes. The inverse relationship between class and fertility that had been viewed as understandable and correct from the vantage point of the Malthusianism of classical economics was considered unacceptable and devastating by those espousing the new biological Malthusianism. Motives were recast. The "prudence" and "pride" of the upper classes became "selfishness" and "excessive materialism." Optimism over nineteenth-century fertility trends turned to pessimism. This pessimism deepened as Lamarckian beliefs about the inheritability of acquired characteristics gave way under the onslaught of Weismann's (1893) contentions that germ plasm was inviolable and the rediscovery of Mendel's 1865 research documenting the statistical regularities followed in genetic transmission. Science seemed to be proving the preeminence of heredity over environment. The differential population growth rates of the nation's racial and class subpopulations assumed a supreme importance.

With biological Malthusianism, the consequence of population dynamics that assumes greatest importance is its impact on the biological quality of a population, not its impact on the prosperity of a people. Its adoption had interesting consequences for the birth control movement. Viewing them from the perspective of classic Malthusianism, one can understand why birth controllers were called neo-Malthusians. Although their solution was one 
of Malthus's vices, their advocacy of birth control as a way of improving one's social and economic position was analogous to Malthus's advocacy of moral restraint. Viewed from the new biological perspective, however, this movement was hardly a solution to the nation's problem. The uneducated, animalistic, largely alien lower classes were thought to be not at all interested in, or capable of, birth control. Increasing access to birth control would simply hasten the fertility decline of the educated native American population, those with the motivation to adopt the small-family ideal. The fact that the birth control movement mainly attracted educated native women made it suspect to the nearly all-male world of academics concerned with population questions. The changed desires, values, and behavior of these women were thought to lie behind much of the move toward smaller families in the first place (Billings, 1893). Biological Malthusians came to view feminism itself as part of the problem.

The twentieth century began, then, with a number of population concerns high on the national agenda. Malthusianism, Darwinism, Teutonism, and neo-Malthusianism were all prominent, and all considered population factors to be of central importance. Biological Malthusians were pessimists who found cause for concern in population trends and felt the need to intervene; restrictionists called for migration changes, and eugenicists called for fertility changes. Birth controllers were optimists who found cause for hope in population trends: birth rates were declining, even in the face of government opposition to the spread of contraception, and this decline meant greater freedom for women and improved living standards. Both movements were "Malthusian," but the added assumptions made by biological Malthusians led to a different population agenda. Meanwhile, a growing group of population scientists was emphasizing the compilation of population statistics and the desirability of treating the causes and consequences of population change from a firm empirical ground.

By the early twentieth century the field of population was being molded by the four factions present at the founding sessions of the PAA. Examining developments in each will uncover the dynamics that led to the formation of coalitions and, eventually, to the establishment of the Population Association of America.

\section{Immigration restriction}

Dislike of immigrants and calls for their exclusion have a long history in the United States. These outbreaks of nativist sentiment almost always had a compositional focus. Aliens were not opposed because the nation lacked food or land for them, but because their presence might change the American character. In the mid-eighteenth century Benjamin Franklin (1961 [1751]: 234) railed against German immigration into Pennsylvania, fearing that the 
"Palatine Boors" would "Germanize us instead of our Anglifying them." He opposed the importation of slaves for similar reasons: "why increase the Sons of Africa, by Planting them in America, where we have so fair an Opportunity, by excluding all Blacks and Tawneys, of increasing the lovely White and red?"4

In the mid-nineteenth century Know-Nothings elected dozens to Congress on an anti-immigrant platform (Bennett, 1988). Catholics, especially the newly arriving Irish, were the unwanted. During the second half of the nineteenth century laws with a racial focus were passed to exclude certain kinds of immigrants (Higham, 1963, 1984). The Chinese Exclusion Act was passed in 1882 to prevent the racial tainting of the American population. That the hard-working, low-wage "coolie" also was thought to threaten the living standard of the average white (Farwell, 1888) lent a populist note to this racism. Theodore Roosevelt (1897: 289) sounded this strain, arguing that had the United States been under "aristocratic" government, "Chinese immigration would have been encouraged precisely as the slave trade is encouraged of necessity by any slave-holding oligarchy, and the result would in a few generations have been even more fatal to the white race; but the democracy, with the clear instinct of race selfishness, saw the race foe, and kept out the dangerous alien." Such selfish, democratic racism led Roosevelt, when president, to pressure Japan to ban the emigration of Japanese laborers to the United States after 1908.

The passage in 1921 and 1924 of national origins quota acts that explicitly discriminated against non-Nordic Europeans, therefore, continued a pattern of racist, compositional concern (Fairchild, 1926: 128-130): “Each time that the threat of dilution by a widely different race has appeared it has been met decisively. The first instance was furnished by the Chinese immigration. . . . The next widely different race to present itself was the Japanese. . . At about the same time a rising current of Hindus was checked. . . . The outstanding feature of the post-War sentiment of the American people was the conviction that the mere exclusion of the nonwhite races did not go far enough in racial discrimination." It was no accident that the president of the Immigration Restriction League for its first five years (1894-99) was John Fiske, the Teutonist. Nor was it an accident that popular support for immigration restriction coalesced around the racial concerns of Francis Walker over the quality of the new immigrants. ${ }^{5}$

The immigration restriction movement clearly followed the precepts of biological Malthusianism (Bushee, 1903: 361): "The economic question is by no means the most important one to consider in the problem of immigration. It is a race question and the birth rate shows the racial group that is to survive." Unrestricted immigration was "the annihilator of our native stock" (Hunter, 1904: 302). Prescott Hall (1904: 170) directly connected the movement with eugenics early on: "while some advanced persons are talking 
of regulating marriage with a view to the elimination of those unfit for other purposes than mere survival . . . we have a unique opportunity, through our power to regulate immigration, of exercising artificial selection upon an enormous scale." The need for restriction was documented by pointing to the high rates of crime, insanity, and pauperism among the new immigrant groups (Bemis, 1888; Mayo-Smith, 1888a; Fairchild, 1912) and their low scores on intelligence tests (Brigham, 1923). For restrictionists, the immigration issue was "mainly a problem of blood," not numbers (Garis, 1926: 666; Ludmerer, 1972b).

If immigration restriction had been pursued for classic Malthusian reasons, it would have assumed different contours. Reducing numbers, not racial exclusion, would have been the goal; restrictionists would have found allies in birth controllers, not eugenicists. A simple response to a "filled-up" America facing resource limitations would be to halt population growth both by restricting immigration and by working to lower fertility. In point of fact, it is difficult to find many taking such a position. Among the few who did so, Louis Harley (1895) argued both for immigration restriction and for policies to increase the economic independence of women in order to hasten fertility decline. Frank Fetter (1913: 13), too, presented a classic Malthusian argument for restriction, even adding that "our view is wholly impersonal and without race prejudice. If the present immigration were all of the AngloSaxon race, were able to speak, read and write English, and had the same political sentiments and capacities as the earlier population, the validity of our present conclusions would be unaffected." But theirs were the uncommon voices.

The biological Malthusianism underlying the immigration restriction movement led to actual positions that were "odd" from a classical perspective. For instance, most restrictionists did not favor lowering the fertility of native American women, nor did they think that immigrants added numerically to the population (Fisher, 1895; Bushee, 1903; Commons, 1904; Fairchild, 1911). They were advocates of Walker's position. Immigrants simply "replaced" natives (Walker, 1891: 642): "That if the foreigners had not come, the native element would long have filled the places the foreigners usurped, I entertain not a doubt." The hope was that immigration restriction would lead to a resurgence of native American fertility. Compositional concerns clearly outweighed fears of overpopulation.

Certain aspects of the restrictionists' arguments, though, did attract support even among groups the movement targeted for discrimination. Central to Walker's theory was the vision of the immigrant as a competitor of the American worker, one who depressed his wages. Obviously, the foreignborn worker already in America might accept this vision and view the potential immigrant, even one from his homeland, as a threat to him as well. From the beginning of the movement, restrictionists (Bemis, 1888; Walker, 1891; Hall, 1904; Hunter, 1904; Robert DeCourcy Ward, 1904; Fairchild, 
1912) presented a populist explanation of the explosion in late nineteenthcentury immigration: a nefarious coalition of steamship lines, railroad companies, and large industrialists worked together to foster this explosion. Their agents scoured the backwaters of Europe, drumming up both customers for the now-inexpensive passage to America and low-wage workers for the industrialists' factories. Restrictionist economists, like Walker and MayoSmith, tended to be "progressives," leaders of the "new" economists who railed against the blind application of laissez faire doctrines when determining policy. Much of their writing had working-class appeal.

The Immigration Restriction League did attempt to gain the support of labor unions. Although it was apparent that they were using a class argument in order to further their racial agenda, the argument could be accepted without the racial baggage. Union members, even ones from the "failed races" of Europe, could hope that by reducing the number of immigrants, their wages might rise and competition for employment might fall. The addition of such "class" reasons for limiting numbers produced a coalition of groups, albeit quite strange, in favor of restriction: Nordic racists inspired by the works of Madison Grant (1916) and Lothrop Stoddard (1920), eugenicists, anti-urban populists, and urban union members. Since the national origins quota acts both limited numbers and discriminated racially, the Boston Brahmin and the Polish coal miner each had a reason to support them.

With the passage of these acts in the 1920s, the immigration restriction movement had largely attained its stated goal of excluding "inferior" races from entry into the United States. ${ }^{6}$ However, the larger objective of the restrictionists' biological Malthusianism, improving racial quality, still could be augmented. Fertility became the central mechanism of future compositional change. Working within an organization broadly aimed at dealing with America's population problem "in both its quantitative and qualitative aspects" (the mission statement adopted at the founding session of the PAA) was an ideal way of pursuing this larger objective. ${ }^{7}$ Henry Pratt Fairchild's instrumental role in establishing the PAA can be considered one restrictionist's response to legislative success.

Immigration restriction and eugenics had similar roots in biological Malthusianism, an extensive sharing of personnel, and an overlapping population agenda. Their principal dissimilarity relates to their relative success. Restrictionists largely accomplished their population agenda, eugenicists had much less success. Factors other than their shared biological Malthusianism influenced their fates.

\section{Eugenics}

The eugenics movement had problems forming coalitions to support its cause. Firmly grounded in biological Malthusianism, eugenicists held positions about class that made it difficult to elicit mass appeal. The movement was 
first established in England by Francis Galton, cousin of Charles Darwin (Kevles, 1985). He argued that "natural ability" was largely an inherited attribute. Using "reputation" measures (citations in dictionaries of eminent figures), Galton (1869) documented the inheritability of "genius" and pressed for selective breeding to hasten the evolutionary process. The high correlation between genius and social class led eugenicists to view class as a biological phenomenon. Their concern over fertility trends was an outgrowth of assuming that the genetically superior rose in the class structure while the genetically inferior sank. With marriage occurring largely within class groups, classes came to be seen as "breeding populations" that passed on sets of genetic traits of a contrasting quality. Viewed in this light, the higher birth rates of the lower classes became a biological problem (Soloway, 1990: 60$85)$. The excessive contribution to the nation's progeny made by the "unfit" moved some (e.g., Pearson, 1901: 26-27) to consider eugenics a way to prevent biological degradation.

In America the eugenics movement gained momentum early in the twentieth century, mainly at the instigation of natural scientists (Haller, 1963; Pickens, 1968; Ludmerer, 1972a). The rediscovery of Mendel's work in 1900 led to the formation of the American Breeders Association in 1903. In 1906 a Eugenics Section of the Association was established to "emphasize the value of superior blood and the menace to society of inferior blood" (Haller, 1963: 62). Chaired by David Starr Jordan, biologist and president of Stanford University, this section included many who were to lead the American movement, chief among these being Charles Davenport. In 1910 Davenport, a Harvard-trained biologist who had gone to England to work with Galton and Karl Pearson, established the Eugenics Record Office, with himself as director and Harry Laughlin as superintendent. Its fieldworkers collected family pedigrees that were used to document the genetic basis of mental and physical conditions. It became the organizational center of the American eugenics movement.

The racial and ethnic diversity of the American population produced a clearly defined stream of racial eugenics in the American movement. Concern over the low fertility of the higher classes melded with concern over the "race suicide" of superior Anglo-Saxons. Since population composition was so obviously influenced by immigration as well as by differential fertility, advocacy of immigration restriction was high on the agenda of American eugenicists. Two years after its own founding, the Eugenics Section of the American Breeders Association established an Immigration Committee, headed by Prescott Hall and Robert DeCourcy Ward, founders of the Immigration Restriction League. ${ }^{8}$

In addition to immigration restriction, advocacy of "positive" eugenics (inducing the genetically superior to increase their fertility) and "negative" eugenics (inducing the inferior to reduce their fertility) were core movement 
policies. Although the need to foster positive eugenics through education and propaganda was discussed, the movement focused its political activities on promoting negative measures. The eugenically "unfit" were classified (Laughlin, 1914): the feebleminded, pauper, inebriate, criminalistic, epileptic, insane, asthenic (weak), diathetic (diseased), deformed, and cacaesthetic (blind and deaf) "classes." A "Model Eugenical Sterilization Law" was drawn up and highly successful lobbying efforts were undertaken to have states pass such laws (Laughlin, 1922). California was notable for actually enforcing its laws; 6,000 "eugenic" sterilizations occurred there from 1909 to 1929 (Gosney and Popenoe, 1929).

Politically, however, the movement had difficulty flourishing in a democratic environment. Although attracting individuals with a variety of ideological proclivities, eugenic assumptions were especially alluring to those with elitist beliefs. A definite antidemocratic strain was present from the beginning. " "Aristogenics" was the label early American eugenicists chose for positive measures. John Commons (1907) attacked the egalitarian assumptions of the Declaration of Independence, argued that equality of opportunity led to a natural oligarchy of the fittest, and suggested that the aristocracy in Europe came to rule over inferior peasants as a result of the workings of biological laws. Later, eugenicists latched upon the results of the Army intelligence tests given to World War I recruits to further their cause. Finding that the average recruit had a mental age of 14 confirmed their worst suspicions about the degradation of the American population. Some were led to draw "un-American" conclusions about the appropriateness of democratic rule (McDougall, 1921; Cannon, 1922).

The very success of eugenicists in establishing the severity of the problem eventually worked against them. Contending that half of the American population possessed subnormal intellects (Stoddard, 1922: 69), that 10 million were in need of eugenic sterilizations (Popenoe, 1928: 410), and that educated women were acting selfishly and diminishing the quality of the nation's germ plasm (Dublin, 1923) did attract attention. But eugenic solutions all entailed elements of coercion. What the eugenicists found problematic, after all, was the result of individual couples making fertility decisions on the basis of their self-interest. Few thought that simple exhortation would turn the tide. ${ }^{10}$ The majority of Americans with "subnormal intellects" were not likely to vote to sterilize themselves, nor were the politically powerful well-to-do likely to be induced to have unwanted pregnancies. "In reality only the truly powerless-the institutionalized-suffered the "remedy" of the eugenicists: forced sterilizations. Perhaps Galton (1904: 5) was correct when he saw the need for eugenics to become a religion to succeed.

Early in the century the triumph of Mendelian genetics aided the American movement, permitting the mantle of "science" to be laid over the endeavor. ${ }^{12}$ Opponents, such as Lester Ward $(1891,1907,1913)$, could be 
labeled outdated Lamarckians who refused to accept biological "facts." As the century progressed, however, the early success the movement had in attracting biologists engaged in genetic research proved to be a liability. Many genetic discoveries of the first quarter of this century could not be easily incorporated into a movement which wanted to believe that traits such as "feeblemindedness" were due to the absence of "a single effective gene," and so could easily be bred out of a population (Davenport, 1920: 302). The most devastating critiques of the movement eventually came from biologists initially attracted to it. By 1927 Raymond Pearl (p. 261) was calling both the teaching and the legislative agenda of the movement "as outworn and useless as the rind of yesterday's melon"; Herbert Jennings (1930, 1931), a former student of Davenport, found the movement's assumptions to be riddled with scientific "fallacies."

With biological Malthusianism's home in the sciences becoming increasingly inhospitable, the establishment of a new policy-oriented discipline centered on solving the nation's population problem "in both its quantitative and qualitative aspects" was a fortuitous development. If race and class were losing their salience in biology, the same was not true in society at large. A congenial refuge, though, was increasingly difficult to find in American social sciences. The preeminent position held by Franz Boas, an ardent and longstanding anti-eugenicist $(1916,1925)$, made anthropology an unlikely candidate. Second-generation sociologists were less enthralled with Herbert Spencer and biological analogies, and more likely to find sociological flaws in standard eugenic assumptions (Thompson, 1924). Additionally, the Chicago School was on the rise, led by a nonracist Robert Park whose community study approach to understanding ethnicity emphasized the importance of environment over heredity (1921: 301-302) and who even found recent immigrant groups making faster progress than earlier ones (Matthews, 1977; Satariano, 1979: 319). By the end of the 1920s, detailed analysis of the socioeconomic correlates of intelligence test scores induced psychologists to offer environmental, not racial, explanations for intergroup differences. ${ }^{13}$ Economists, although often expressing racist and eugenic sentiments, had never systematically incorporated biological Malthusianism into their discipline. A separate "population science" promised biological Malthusians a new, more hospitable, base from which to promulgate their cause.

\section{Birth control}

In 1919 Margaret Sanger (p. 11) distinguished between the eugenicist and the birth controller: "Eugenists imply or insist that a woman's first duty is to the state; we contend that her duty to herself is her first duty to the state. . . [ [I]t is her right, regardless of all other considerations, to determine whether she shall bear children or not, and how many children she shall 
bear if she chooses to become a mother." The birth controller's desire of assuring every woman access to contraception differed from the eugenicist's desire of molding individual fertility to the larger interest of the group. One advocate had an economic end, improving the individual's living conditions by preventing unwanted pregnancies, the other had a biological end, improving the race. One sought the elimination of laws that equated birth control and obscenity, the other sought the enactment of laws that would induce biologically prudent reproduction. With such potentially conflicting goals, the wonder is that birth controller and eugenicist could come to see each other as allies.

Aspects of nineteenth-century American demographic fact and theory seemingly supported the spread of a birth control movement. Mayo-Smith (1888b: 203) depicted the "ideal" population as "one where there is a small number of births, a small number of deaths, and a long average life . . . where there is a high standard of living, where there is prudence and selfrestraint." Political economists recognized that beneficial lower death rates logically required lower birth rates if Malthus's positive checks were to be avoided. For most of that century low fertility had been related to responsible parenthood and prosperity. And at century's end, the new problem of a "filled-up" America seemed to call for birth control as a solution. Yet, throughout the nineteenth century there was little institutional support for the spread of contraception. It was treated more as a moral than an academic topic, even by students of population.

Malthus had labeled the practice of contraception a "vice" and spoke little of its possible impact on fertility levels. In America several tracts were published in the 1830s discussing the topic, one recommending withdrawal (Owen, 1831) and another douching (Knowlton, 1832). There was some effort at suppression (Reed, 1978: 6-13), but systematic suppression did not occur until the 1870 s with the passage of the Comstock laws that banned the importing, conveying, or mailing of "obscene, lewd, or lascivious articles," a category that included contraceptive information and devices. A moral crusade aimed at controlling venereal disease and eliminating prostitution, pornography, and all aspects of a sexual double standard mobilized many middle-class women. Contraception permitted sex without reproduction and made fornication and adultery "penalty free." Deprived of condoms, perhaps males would forgo prostitutes. In the public arena, moral crusaders such as Anthony Comstock succeeded in associating contraception with illicit sex. Meanwhile, the increasing percentage of married couples who were adopting the practice simply to have smaller families did so quietly. ${ }^{14}$

Contraception's association with radical feminism early in the twentieth century did little to advance its public acceptability. Emma Goldman, the anarchist, attended the 1900 Paris Neo-Malthusian Conference and began advocating contraception and "voluntary motherhood" in lectures and in 
her periodical, Mother Earth. Margaret Sanger, who did most to establish the birth control movement in the United States, initially adopted Goldman's orientation to the topic. A one-time socialist and member of the International Workers of the World, Sanger founded The Rebel Woman in 1914 to bring knowledge of contraception to the masses. Distributed through IWW local branches, it contained articles advocating birth control as a means of frightening the "capitalist class" and attacks on marriage and private property. Not only was the ire of Comstock aroused, who prosecuted her, but even many radicals were offended (Kennedy, 1970: 15-26).

Support for contraception from established institutions was slight. Most physicians were too insecure of their own standing to participate in such a controversial crusade. ${ }^{15}$ They worried about contraception's association with adultery, premarital sex, feminism, and medical quackery (Kosmak, 1917: 271-272). A leadership of lay people, often female and radical, made even acquiescence to movement goals by this largely male profession difficult. Many natural and social scientists were too enamored of biological Malthusianism to support a movement whose policies might work against racial betterment. They contended that the "prudent and thoughtful" ("whose children the race needs") would be the ones to practice birth control, "while even possession of a knowledge of contraceptive methods will not affect the reckless and improvident" (Clarke, 1896: 357; Popenoe, 1917b: 6; Gosney, 1931: 202). Making contraception more accessible, therefore, would necessarily have a deleterious impact on the quality of a population. ${ }^{16}$ The rapidly declining fertility of the college-educated seemingly confirmed their suspicions (Smith, 1905; Emerick, 1909; Nearing, 1914; Phillips, 1916; Popenoe, 1917a). Many also objected to the environmentalist thrust of birth control propaganda. The claim that fewer and more widely spaced offspring would lead to a higher-quality population clashed with their biological determinism: "the quality of a child is determined much more by the character of his ancestry than by the number of brothers and sisters he has" (Popenoe, 1917b: 6).

Sanger, however, quickly became politically astute in her birth control advocacy. Her second periodical, the Birth Control Review, contained testimony that positioned the movement in a positive light: heartrending pleas for help from poor women whose medical problems made additional pregnancies life-threatening; ${ }^{17}$ and intellectual pieces associating the need for birth control with global and national problems of overpopulation (Dekker, 1918; Sanger, 1920; Martens, 1920; Pearl, 1923; East, 1923). Police actions, instigated by the Roman Catholic hierarchy, to prevent birth control meetings and to close Sanger's clinic were skillfully exploited. The established press was aroused and defended her First Amendment rights of free speech. Society women were mobilized and became volunteers and supporters of her cause.

Sanger, many of her attachments to the Left severed in a 1917 dispute, also began remolding her movement into a middle-class one that had but 
one focus: birth control (Kennedy, 1970: 108-126). Personally, this shift was fortunate since in the Red Scare of 1919-20 some of her former comrades suffered arrest and others, including Goldman and Alexander Berkman, deportation to the Soviet Union (Bennett, 1988: 183-199). Organizationally, this shift produced a more politically powerful and effective movement. Educated, middle-class women, recent participants in the successful suffrage movement, were more receptive to Sanger's message and more effective fighters for reform than poor, immigrant women. If Sanger had not shifted her focus, leadership of the movement would likely have passed from her hands. As early as 1915 a variety of birth control leagues were organized by middle-class, reform-minded women. Sanger viewed Mary Ware Dennett as a particular threat to her leadership. Dennett (1926) had a clear legislative agenda - to eliminate contraception from inclusion in Comstock laws-and her presence probably inspired a number of Sanger's policy positions (Back, 1989: 53).

Throughout the 1920s many of the assumptions of upper-middle-class progressives were incorporated into the movement, including eugenic ones. Sanger readily adopted biological Malthusianism. In 1925 she argued (pp. 31-32) that certain conditions "demand the exercise of birth control": having a heritable disease; having already borne a defective child; and even being poor. Addressing students at Vassar College in 1926 she claimed that the national origins quota acts did not go far enough in controlling "the quality of our population." We needed to "cut down the rapid multiplication of the unfit and undesirable at home" as well. She suggested giving a government pension to unfit couples who undergo sterilization. Advocacy of such negative eugenics was used to deflect attention from positive measures that might restrict the reproductive freedom of her new constituents (p. 299): "There is only one reply to a request for a higher birth rate among the intelligent, and that is to ask the government to first take off the burdens of the insane and feebleminded from your backs." As birth control became a middle-class movement, calls for socially responsible reproduction were appended to traditional rhetoric emphasizing individual reproductive freedom.

This ideological shift helped Sanger when she turned to scientists and academics for support as part of her quest for legitimacy. She was able to find allies for the movement among academics concerned with population issues. Although some eugenicists, most notably Davenport, ${ }^{18}$ found the conflicts in the two movements' assumptions too significant for compromise, others thought that expanding access to contraception, especially among the lower classes, would prove an effective component of a negative eugenic strategy. Roswell Johnson (1922: 16), for example, argued that since "the Aryan stock is today the most given to Birth Control," then "laws suppressing information and means of Birth Control should be removed" lest the race suffer "by the ignorance of inferior stocks." Clarence Little (1926: 7, 34) thought that bringing birth control to the poor might be a more effective 
eugenic strategy than trying to increase the fertility of the "higher classes," who prefer having "their pet Pomeranians and other things of that kind rather than children."

Sanger fostered the support of these academics by organizing and sponsoring a number of conferences during the 1920 s on birth control, neoMalthusianism, and population. ${ }^{19}$ She sought their advice when establishing a research agenda at her clinic and asked them to assume key board positions in a variety of birth control organizations. She even solicited the $\$ 600$ from the Milbank Memorial Fund needed to fund the founding meeting of the Population Association of America (Reed, 1978: 204). Although many biological Malthusians were suspicious that the birth controllers' eugenic garb might just be for show, ${ }^{20}$ by the 1930s a majority had come to see the birth control movement as serving a eugenic purpose (Hankins, 1931; Burch, 1932; Osborn, 1937).

A new interpretation of modern fertility trends contributed to this assessment. Once a clear downward trend was evident in the fertility of all groups (Popenoe, 1930; Burch, 1932), the "transitional" nature of modern fertility decline became evident. The inverse relationship between class and fertility that panicked the turn-of-the-century eugenicist might only be a temporary phenomenon caused by the higher classes' earlier acceptance of contraception. Burch (1932: 64) even argued that the end of the transition would see a positive relationship between class and fertility as the productive classes, no longer having to support a burgeoning dependent class, redirected their resources to raising larger families. He concluded that if made "available to a whole community, birth control as a social device does not produce 'class suicide' but precisely the opposite-the survival of the classes whose increase is needed to serve the best needs of the whole population."

As birth control became a progressive, middle-class movement, it adopted much of the ideology of biological Malthusianism. That birth controllers would wish to join forces with eugenicists and restrictionists to form an association aimed at dealing with America's population problem "in both its quantitative and qualitative aspects" indicates how complete this transformation had become by 1930. At the end of the 1930s, Fairchild was contending that the eugenics and birth control movements "have now come to such a thorough understanding and have drawn so close together as to be almost indistinguishable" (quoted in Gordon, 1977: 14). By then, ironically, association with eugenics hardly worked to enhance the legitimacy of the birth control movement.

\section{Population scientists}

The last faction present at the founding session of the PAA, the population scientists, is difficult to portray in a definitive fashion. Demography was an 
intellectual activity at the beginning stages of institutionalization. ${ }^{21} \mathrm{~A}$ few universities offered an undergraduate course on "population," and a textbook (by Reuter) appeared in 1923, but there were no graduate programs in the discipline. ${ }^{22}$ The requisites for establishing a separate discipline, however, were developing. The demand for individuals adept at analyzing population data was reaching significant levels: the Census Office became a permanent entity in 1903 (Anderson, 1988: 118); more states were systematically collecting vital statistics (Vance, 1959: 288-289); and private companies, especially those in the life insurance industry, were increasingly sophisticated users of population statistics. In 1913 Willcox, using the term to specify a particular profession, spoke of the need to "increase the supply of demographers" in the United States.

By that time a number of individuals in academia had begun to think of themselves as specialists in the population field. Some were biologists, nearly all with eugenic leanings, many of whom went on to play a role in the establishment of genetics in the United States (Ludmerer, 1972a) ${ }^{23}$ Others were economists, statisticians, and sociologists who had become engrossed in the gritty analysis of population data in the context of the late nineteenthcentury revival of interest in "statistics." These social scientists were to play the central role in the establishment of demography in the United States.

The first formal course in statistics was offered by Mayo-Smith at Columbia University in 1880 (Seligman, 1901: 41-42; Lundberg, 1933). As used at the time, the term referred as much to substance as to method. MayoSmith's Statistics and Sociology (1895), a compilation and interpretation of population statistics, came close to being a textbook in demography. ${ }^{24} \mathrm{He}$ held (pp. 1-16) that "those facts of population which reveal the laws of social organization are the facts which are of importance for Sociology, and no others." Through "observation" and "quantitative analysis," generalizations about "cause and effect" in the social realm can be "induced." This knowledge could then be used to solve social problems. Mayo-Smith's positivistic empiricism was a precursor of American demography (Vance, 1959: 290). Although dying at a young age in 1901, he directly influenced, either as teacher or colleague, many who became key population scientists in the first third of this century.

Walter Willcox, perhaps the preeminent population scientist of that era, was Mayo-Smith's student (Aldrich, 1979: 2). Willcox began teaching statistics and social science at Cornell University in 1891 and remained there until 1931; Frank Notestein was one of his students. ${ }^{25}$ Franklin Giddings came to Columbia to teach statistics at Mayo-Smith's request in 1891, and jointly taught a "sociology and statistics" seminar with him until 1901 (Davids, 1968: 63). Giddings in the sociology department and Robert Chaddock in the economics department kept Mayo-Smith's empiricist tradition alive at Columbia and trained a "suprising number of leaders of American de- 
mography" (Lorimer, 1959: 162), among whom were Warren Thompson and Clyde Kiser.

The work of these empirically minded population scientists is distinguishable from those who wrote on population themes as movement advocates. The exchange between Willcox $(1906,1912)$ and Fairchild (1907, 1912) on the significance of turn-of-the-century immigration is illustrative. Willcox consistently tested the validity of Fairchild's assertions. For example, he (1912: 69-70) responded to Fairchild's contention that immigration is increasing "pauperism and crime," by examining the available data. Controlling for sex, age, and region, he found "nothing to prove that the foreignborn contribute more largely to the almshouse population or the prison population than do the native whites." Although empirically demolishing nearly all of Fairchild's objections to unrestricted immigration, he did not reject the movement because he found one with which he could agree: it threatened American standards of wages and living.

Fertility trends, likewise, received a distinctive methodological and substantive treatment. Willcox (1911: 495-496) measured nineteenth-century fertility trends by calculating child/woman ratios from census data, and found that "the decrease in the proportion of children began in the United States as early as 1810 and has continued at about the same rate ever since." E. A. Goldenweiser (1912) used this finding to cast doubt on Walker's theory of fertility decline, still a linchpin in the restrictionist's argument. Warren Thompson's "Race suicide in the United States" (1920), although having a biological Malthusian title and conclusion, was primarily a sociologically insightful examination of regional and class variations in vital rates in which the fertility reasoning of each of four social classes was outlined. Louis Dublin and Alfred Lotka (1925: 328-329) developed "intrinsic" vital rates that controlled for the age structure's influence on crude rates, and dramatically announced that the average American woman in 1920 was having only half a child more than was needed to maintain a stationary population. Whelpton (1928) devised the component method of population projection and forecast a significant slowdown in US growth. These analyses began a sea-change in population concerns: fears of overpopulation gave way to rising concern over depopulation.

Belief in the empiricist tradition did not preclude ideological commitment. During the first third of this century, population scientists largely accepted the precepts of biological Malthusianism. Mayo-Smith concluded from his extensive study of immigration statistics that restriction was needed to protect the nation from the "depraved dregs of European civilization" (1888c: 412-413). Willcox considered the low fertility of the "native stock of the New England States" to be a national dilemma since that stock was hereditarily "better endowed" (1916b: 127). The Advisory Council of Davenport's Eugenics Society of the United States (Eugenical News 10, no. 2: 10- 
11) was replete with population scientists, including Giddings and Willcox. Lorimer and Thompson served on the Society's Board of Directors, even after overtly antisemitic apologies for Nazi eugenic measures had appeared in its official organ during the 1930s. Louis Dublin, a Jewish immigrant from Lithuania, called himself a eugenicist (1923:378) and questioned the quality of recent immigrants (1920:8): "Have you no reservations as to the power for self-government of the newcomers or as to their capacity to carry on the traditions of America . . . ? [W] are now remaking the stock out of which the new America will arise."

This ideological commitment did affect the work of population scientists. Willcox and Thompson concluded their analyses of fertility trends with calls for positive eugenics (Willcox, 1916b: 127; Thompson, 1920: 143145). Thompson (1924: 238) and Dublin (1918: 209; 1923) deplored the move toward equality for women in education and the workplace because it encouraged the exceptionally endowed to forgo large families, and both writers called for "birth release" and not "birth control." Dublin (1926b), usirg intrinsic measures to heighten a sense of crisis, labeled birth control a national problem since it made depopulation more likely. Census Bureau population scientists (e.g., Hill, North, and Rossiter) championed Walker's theory well into the twentieth century (Anderson, 1988: 137), although it never had much empirical support. The very categories they used to analyze population trends reflected racial thinking. William Rossiter (1907: 320) considered the new immigrants to be different "from the American in race, language, and ideals"; he worried (1909a: 80) about "an increasing drift away from Anglo-Saxon lineage and possibly from Anglo-Saxon ideals, as the later or foreign element overtakes and passes the native stock." His census monograph, A Century of Population Growth (1909b), attempted to divide the white population of 1900 into "native" (descendants of the 1790 population) and "foreign stock." Joseph Hill spent much of the 1920s refining Rossiter's research so that scientifically based ethnic quotas could be used to implement the national origins quota acts. In Hill's 1911 study of the Fecundity of Immigrant Women (pp. 738-739) his "main object" was "to arrive at a comparison as regards fecundity between the different nationalities or races." He focused on "pure stock" ("such as the Irish, the Germans, the Scandinavians, and the native Americans") and excluded from the analysis all women of "mixed races." Simon North (1918: 41-42) characterized recent immigration as an "irruption of alien races," worried about "the problem of race admixture," and warned that by 1950 the population might be "three fourths or more of foreign blood."

Population scientists believed that their empiricism would preserve their objectivity. ${ }^{26}$ That it did not, demonstrates their naiveté. Yet population studies was never subsumed by the eugenics movement. Much of the population scientists' work was of little eugenic import. Dublin's core interest, 
for example, was improving the measurement of mortality and morbidity. The articles in which he voiced eugenic opinions were incidental forays into the public arena about which he later had misgivings (1966: 140). Much of the increased interest in population was unrelated to biological Malthusianism, and the field's prospects were not tied to the fate of that ideology. Population scientists even occasionally assumed a critical stance when assessing eugenic assumptions. Willcox (1916b: 126; 1931: 92-103), for example, pointed out difficulties with Walker's theory, and Thompson (1924: 229-230) objected to using a high correlation between IQ and social status as proof that innate intelligence is greater in the upper classes. Absorbed in deciphering population trends, however, they often appeared unaware of their own ideological presumptions. When biological Malthusianism fell into disrepute, this inattentiveness proved useful. Past associations were quickly forgotten.

By 1930 the need for a national organization that would focus exclusively on population issues was evident. Foundation support for population research had begun (Kiser, 1971), government interest was growing, and the International Union for the Scientific Investigation of Population Problems had recently been formed. Divided by disciplinary background and type of employment, population scientists needed the bonds that a national association could provide. Being few in number and possessing few shared credentials, they had little reason to want an overly exclusive association. The presence of restrictionists and eugenicists was hardly a problem. Many of them were academically more illustrious than the population scientists, and promised to add distinction to the organization. Ideological differences were slight. ${ }^{27}$ The inclusion of birth controllers was more troublesome. Some population scientists objected on principle, contending that birth controllers were worsening the nation's population problems. Some objected on practical grounds, fearing that Sanger's notoriety, and her lack of a college degree, would detract from the PAA's professional image.

\section{Conclusion}

Accounts of the founding of the Population Association of America often maintain that the "scientists" took command of the Association from the beginning (Vance, 1959: 304-305; Lunde, 1981). Two pieces of evidence are offered: defeat of the nomination of Margaret Sanger for a high position in the Association; and the forming of a self-electing College of Fellows to run the PAA, making a takeover by stacking the membership difficult. There are problems with this evidence. Although much of the discussion about the Association's purpose was framed in terms of "science" rather than "action," it must be remembered that eugenicists considered themselves scientists. The rebuff of Sanger might reflect more a residual distrust of birth controllers by 
all the other factions present, especially the eugenicists, than an effort by the population scientists to check the activists. ${ }^{28}$ The College of Fellows included as charter members all the initial invitees to the founding meeting, thereby making the population scientists a distinct minority. ${ }^{29}$ Finally, the election of Fairchild as president of the PAA for its first four years better illustrates the strength of biological Malthusians than the dominance of population scientists (Reed, 1978: 204). Fairchild uniquely personified the disparate elements of early twentieth-century American population thought: a nativist with clear eugenicist leanings who had an academic post teaching courses in population studies while serving on the Board of Directors of Margaret Sanger's birth control clinic. Although a representative president, he was neither a population scientist nor a detached scholar. ${ }^{30}$

The PAA did quickly come to be dominated by population scientists. Events of the 1930s were instrumental in that development. Nazi actions largely discredited the eugenics movement in the public's eye, and advances in genetics continued to distance the movement from the scientific community. Birth controllers achieved much political success on their own and had less need to associate with population specialists; growing national concern with depopulation, a problem for which birth control offered no solution, also made such association increasingly awkward. Finally, the Depression greatly increased the demand, within government and foundation circles, for the detailed demographic analyses that population scientists could provide (Vance, 1959: 293; Notestein, 1971: 71-72; 1982: 662-663). The Hoover and Roosevelt administrations sponsored major studies by population scientists. ${ }^{31}$

In 1935 the PAA sought New Deal connections, as well as new members, by sponsoring a conference on "Population Studies in Relation to Social Planning" in conjunction with its annual meeting in Washington, D.C. (Kiser, 1953: 109). The Depression was molding the discipline. The utility of demographic analysis in the planning process increasingly dominated the agenda of PAA meetings, and biological Malthusian themes, hardly in accord with New Deal political sentiments, quickly disappeared. Sufficient foundation interest in the field developed to fund the establishment of Princeton's Office of Population in 1936 (Kiser, 1971: 15). By the end of the decade American demography was assuming its current form, largely divorced from biological Malthusianism. Lacking their own disciplinary base in the university, demographers moved to mold the PAA into their exclusive professional organization.

Today only traces remain of the PAA's more contentious beginnings. The 1931 mission statement, carefully crafted to appeal to every constituent present at the founding session, has never been changed (Lunde, 1981: 482). Yet few of today's members even know that their organization's pledge to solve the "qualitative aspects" of population problems originally had eugenic 
intent. ${ }^{32}$ This innocence is not accidental. Demography has become what the population scientists wished, an empirical science in which generalizations are firmly grounded in quantitative analyses of demographic variables. A result of this success is that histories of American demography tend to focus exclusively on the empiricist tradition. As treatments of population thought, they are truncated in time and scope: witness Notestein (1971: 7172): "we had arrived at the mid-1920s with rather low levels of interest in population on the part of the public, business, academics and government, but with a scattering of interested people drawn from a wide range of fields producing solid work. Moreover, the nonsense, to the extent that it existed, was not very important because no one paid much attention to that either." This was the time during which Calvin Coolidge (1921) proclaimed in Good Housekeeping that "Nordics propagate themselves successfully" but do not "mix or blend" well with other races, and national origins quota acts were passed to preserve the American population from such mixing!

A broader definition of the field would correct such astigmatism. Population studies can be viewed to be about shaping a society's membership list, especially about altering the list's "numerical and qualitative properties" (Demeny, 1988: 454). This definition recognizes that changes in numbers are of interest only to the extent that they make it more or less difficult to attain some preferred end. The valuative dimension of the field is acknowledged, and those individuals whose interest in population is "ulterior," not limited to the accurate description and analysis of demographic processes, are recognized as full participants in the field.

An examination of American population studies during the early part of the twentieth century highlights the valuative dimension of the field. Population concerns have derived from a host of considerations. Historically, race and class have played more prominent roles than any objective consideration of the commonweal. The overt use of racial and class considerations by various factions of population students, each claiming to have the interest of the commonweal at heart, is what makes turn-of-the-century population studies so distinctive. With different sets of assumptions producing discordant appraisals of population trends, there was pressure to consciously confront the valuative dimension of population studies, to choose sides.

Today, American demographers are tempted to ignore this dimension. Events of the twentieth century have illustrated the dangers entailed in using race and class criteria to evaluate demographic trends. Contemporary definitions of population problems, domestic and international, have an impartial aura to them, whether it be the problem of unwed motherhood or rapid population growth. Seemingly, only one acceptable population value exists in the field: maximizing the economic welfare of individuals. With such a consensus, demographers find themselves with no need to choose sides and no need to consider the valuative dimension of their field. They can simply focus on increasing the accuracy of their demographic analyses. 
There are problems with ignoring the valuative dimension, though. Events of the twentieth century illustrate not only the danger of employing racial and class population values, but also the continued power these factors have as determinants of demographic trends and policies. Demographers may assume that no debate over population values exists, but evidence suggests otherwise. Populations are still being shaped to conform to racial or ethnic preferences. Genocide, a dramatic example of such shaping, is regularly attempted. Pronatalist policies, which have become increasingly common, often have a compositional facet to them. Stimulating immigration is usually a more economical way of increasing population size than stimulating fertility. When the importation of well-trained immigrants is possible, electing to implement a pronatalist policy implies a desire to influence the character as well as the number of new additions. Of course, the migration practices of nations are still rife with provisions and exceptions that favor the entrance (or exit) of particular groups. Many values, not just utilitarian ones, continue to influence demographic behavior. Understanding trends in mortality, fertility, and migration requires recognition of the valuative dimension. Participation in the formation of population policy requires the making of value choices.

A look back, with open eyes, at all the parents of American population studies reminds us that the valuative dimension has been an intrinsic component of the field from its beginning. Seeing it adds a fullness to our understanding of the field. Ignoring it distorts reality.

\section{Notes}

An earlier version of this essay was written for and presented at the Annual Meeting of the Social Science History Association, Minneapolis, 18-21 October 1990, as part of the session "The Political Economy of Demography: The Role of Ideology and Power in the Definition of Population Issues."

I The following is the list of "Persons Requested to Attend Second Conference on Population Association" as found in the PAA Archives (Box 7, File 123). Those with an asterisk after their name were recorded as having attended the Conference: Prof. Ray E. Baber, * Dr. O. E. Baker, Prof. John A. Black, ${ }^{*}$ Dr. Isaiah Bowman, Mr. Guy Irving Burch,* Dr. C. G. Campbell, ${ }^{*}$ Prof. Niles Carpenter, ${ }^{*}$ Prof. Robt. E. Chaddock, * Dr. C. B. Davenport, Dr. Robert L. Dickinson, ${ }^{\star}$ Prof. Clarence G. Dittmer, ${ }^{*}$ Dr. Louis I. Dublin, ${ }^{*}$ Mr. Lawrence B. Dunham, Prof. Edward M. East, Dr. H. P. Fairchild, ${ }^{*}$ Dr. C. J. Galpin, Prof. James W.
Glover,* Mr. Eugene S. Gosney, Prof. Frank H. Hankins, ${ }^{\star}$ Mr. Joseph A. Hill, Mr. Norman L. Himes, ^ Prof. Samuel J. Holmes, Prof. Ellsworth Huntington, * Prof. H. S. Jennings, Hon. Albert Johnson, Prof. Roswell Johnson, Mrs. F. Robertson Jones, ${ }^{*}$ Dr. Vernon Kellogg, Dr. George W. Kosmak, ${ }^{\star}$ Prof. Robert R. Kuczynski,* Dr. H. H. Laughlin, Dr. Clarence C. Little, ${ }^{\star}$ Dr. A. J. Lotka, ${ }^{\star}$ Mr. Robert S. Lynd, ${ }^{*}$ Prof. R. M. Maclver, Dr. C. E. McGuire, ${ }^{*}$ Prof. Wesley C. Mitchell, Dr. Stuart Mudd, Prof. Wm. F. Ogburn, Mr. Frederick Osborn, " Prof. Raymond Pearl, Mr. Adamantios Th. Polyzoides, ${ }^{\star}$ Dr. Paul Popenoe, Prof. Lowell J. Reed," Prof. E. B. Reuter, Prof. E. A. Ross, Mrs. Margaret Sanger, ${ }^{*}$ Prof. J. J. Spengler, Mr. W. M. Steuart, Mr. Edgar Sydenstricker, Prof. Alonzo Taylor, Dr. T. Wingate Todd, Miss Ruth Topping, ${ }^{\star}$ Mr. Leon S. Truesdell,* Prof. Robert DeCourcy Ward, Prof. P. K. Whelpton, ${ }^{*}$ Mr. Leon F. Whitney, ${ }^{*}$ Prof. W. F. Willcox, ${ }^{\star}$ Dr. Linsly Williams, ${ }^{*}$ Prof. E. B. 
Wilson, Miss Virginia R. Wing, Dr. Clark Wissler, Dr. A. B. Wolfe, ${ }^{*}$ Prof. Robert M. Yerkes; and also Prof. J. P. Chamberlain, ${ }^{\star}$ Mr. Leonard Hsu, ${ }^{*}$ Mr. John Kingsbury, * Mr. Frank Lorimer, ${ }^{*}$ Mr. Frank Notestein,* and Mr. John K. Wright. ${ }^{*}$ The last six individuals all attended the Conference and were penciled in at the end of the list. This might mean that they did not receive a formal letter of invitation, but happened to attend the founding session, which was scheduled to coincide with the annual meeting of the Eugenics Society. Misspellings on the list were corrected when noticed. Several individuals not recorded as attending the Conference in Archive documents were, nonetheless, elected officers of the Association: William Ogburn, Vice-President; O. E. Baker, member of the Executive Committee; and Raymond Pearl, member of the Executive Committee. The report on the Conference appearing in the June 1931 Birth Control Review (15, no. 6: 184-185) implies that these three individuals did attend, and also gives the institutional affiliation of all who were present. One major American population scientist not on the list of invitees to the Conference was Warren Thompson. He was, however, elected Second Vice-President of the Association at its spring 1932 meeting.

2 Mayo-Smith's and Walker's treatments began a series of works that took the end-ofthe-frontier thesis and applied to it Malthusian theory: end of the frontier meant limits, declining marginal returns, and pressure of population on resources. Well into the second decade of the twentieth century, writers were arguing (Fetter, 1913; Thompson, 1915; Durand, 1916) that the American standard of living had not increased in decades, that this stagnation was due to population growth, and that the country's material progress was being held in check by Malthusian limits (Fetter, 1913: 9): "Since 1896 food and other farm products have almost steadily advanced in price at a more rapid rate than general prices; since 1898 exports of foodstuffs from the United States have less steadily, but none the less surely declined. In the past twenty years the general progress in science and the technical arts has been phenomenal. . . . Why have real wages risen so slowly or even fallen? ... In large part the explanation must be found in the fact that we have passed the point of diminishing returns in the relation of our population and resources."

3 A remark by Mayo-Smith (1888c: 411 ) is fairly typical of the late nineteenth-century use of Darwinian logic by American social scientists: "It is the right of the higher civilization to make the lower give way before it. . . . The higher civilization has a moral right to triumph over the lower, for it is in this way that the world progresses." Early sociologists in particular were attracted by the biological analogy. It was upon reading Herbert Spencer's Study of Sociology that William Graham Sumner left his clerical post and took an academic post at Yale. Lester Ward, a paleontologist by training, was also taken with the utility of Darwinian and Spencerian thought, and initially drew eugenic deductions ( 1886 : 340-350). Among American eugenicists, this Darwinian/Spencerian tradition remained in place well into the twentieth century through the writings of David Starr Jordan and his pupil, Paul Popenoe. In 1910, Johnson (p. 59), still noting Spencer's argument that all charity must end if "sustentative selection be again allowed full scope," recommended that "legislators and philanthropists should give the preference, other things being equal, to those institutions which save people with good inheritable qualities, running all others, as far as possible, on a celibate basis."

4 These compositional concerns were an outgrowth of Franklin's belief (1961 [1751]: 233) that there is "no Bound to the prolific Nature of Plants or Animals, but what is made by their crowding and interfering with each others [sic] Means of Subsistence." He reasoned (p. 232), with almost Darwinian logic, that allowing "Foreigners" into a land, especially industrious ones, would not add to its population but only work to "gradually eat the Natives out." Walker definitely had a precursor in Franklin.

5 Ross (1901: 88) enhanced the political utility of Walker's theory by labeling it race suicide: "For a case like this I can find no words so apt as 'race suicide'.. . . The higher race quietly and unmurmuringly eliminates itself rather than endure individually the bitter competition it has failed to ward off by collective action." As president, Theodore Roosevelt capitalized on the concern (1907: 550), 
calling race suicide "the greatest problem of civilization," since it results in "the elimination instead of the survival of the fittest."

6 There was an attempt (Garis, 1930) to argue that allowing easy immigration of Latin Americans across the southern borders of the United States defeated the "biological, economic, and social advantages" gained from passage of the national origins quota acts. Public concern never developed over this issue, however, perhaps because the destination of these immigrants was the rural areas of border states, not large Northern cities.

7 The PAA pledged to promote "the improvement, advancement, and progress of the human race by means of research with respect to problems connected with human population, in both its quantitative and qualitative aspects." (Article II of the Constitution of the PAA, revised in July 1974, retains this language.) When this mission statement was written, the expression "quantitative and qualitative" referred to a widely used bifurcation of population problems into those of numbers and those of genetic quality (CarrSaunders, 1922: 17-18; Dublin, 1926a: 6; Thompson, 1930: 335; Lorimer and Osborn, 1934: 21). As Edward Reuter (1923: 5-6) expressed it: "Problems of the population fall into two main divisions. On the one hand is the question of numbers and increase; on the other is the question of capacity and social worth of the individuals composing the group." This bifurcation corresponded closely with the distinction between classic Malthusianism and biological Malthusianism.

8 The overlap between the two movements was extensive. Hall and Robert DeCourcy Ward actually considered changing the name of the Immigration Restriction League to the Eugenics League.

9 In 1907 Lester Ward (p. 709) called the movement "the most complete example of the oligocentric world-view which is coming to prevail in higher classes of society and would center attention of the whole world upon an almost infinitesimal fraction of the human race and ignore the rest." Ross (1912: 1314), a populist with eugenic leanings, noted with suspicion the elite's support of eugenics: "let us own frankly that Science can be twisted to the support of plutocratic arrogance. Dar- winism strips the commonplace man of the dignity that attached to him as a son of God and, moreover, gives the successful a chance to parade themselves as the fittest."

10 Some comprehensive programs were outlined. Ross (1920:7), for instance, would transfer "from the individual to the community" the "economic burden of race continuance" borne by couples who "came up to a certain standard of inheritance, capacity, and character." Such couples would be given a "state allowance for healthy children born," and their offspring would be provided with "free medical care," "free schooling," and "free meals at school." Meanwhile, "compulsory school attendance laws and antichild-labor laws" could be passed to increase the costs of having children and thereby reduce the family sizes of nonsuperior "greedy fathers" who now benefit from large families.

11 The need for state intervention and coercion did present somewhat of a conundrum for biological Malthusians. With a clear idea of who the fittest were, they (Mayo-Smith, 1888c: 416; Roosevelt, 1897) knew that "the state is often obliged to interfere in the process of natural selection in order to make sure that the really fittest survive." But a strict Darwinian definition of biological superiority would be based upon reproductive success. How could the more fit need help in competing reproductively with the less fit? The answer had to do with the greater sensitivity and higher level of civilization of the more fit (Mayo-Smith, 1888c: 411; Walker, 1896: 828). As Ross (1912: 86) put it, the old-stock American was "the victim of too much humanitarianism and too little common sense." Intervention was needed to counter the biologically deleterious consequences of such benevolence.

12 The case was quite different in Great Britain, where Pearson based much of his eugenic theorizing not on Mendelian genetics, which he "scoffed" at, but on traits being statistically normal in their distribution (Kevles, 1985: 36, 43-44).

13 Carl Brigham (1930) even recanted the racial theorizing contained in his earlier work (1923). See Samelson (1978) for a treatment of psychology's move away from "race psychology" during the 1920s. 
14 Since the contraceptive practices of married couples were rarely discussed in public, nineteenth-century students of population never had definitive evidence that this was the major reason for declines in the birth rate. Spencer's biological explanation of the decline (1852), though, was never wholly accepted. Some, like Nathan Allen $(1882,1883)$, believed that both a reduction in fecundity and a change in tastes worked to lower the fertility of the more refined. By 1893, however, John Billings ( $p$. 474) focused exclusively on contraception, asserting that declining birth rates were due to "the deliberate and voluntary avoidance or prevention of child-bearing on the part of an increasing number of married people, who not only prefer to have fewer children, but now know how to obtain their wish." In 1916 Walter Willcox (1916b: 126) could say that "there is not a single one among the experts who denies that this is the great underlying cause of the modern decline in the birth rate."

15 William Robinson and Robert Dickinson are notable exceptions (Kennedy, 1970: 173; Reed, 1978: (43-193).

16 This position was the original eugenic response to neo-Malthusianism. Both Galton and Pearson expressed their opposition early and vociferously (Soloway, 1990: 92-94). In the United States, this reasoning was also applied to races (Ross, 1921: 134): "it is certain that the brighter races will be earliest to look ahead and limit the size of the family, while the dullard races will be the last to abandon the blind fecundity which characterizes the animal." This racial application permitted eugenicists to elaborate a "global" reason for all low-birth-rate peoples to construct a bulwark of restrictive immigration laws to avoid being subsumed by a tidal wave of inferior migrants (Ross, 1921, 1927; Stoddard, 1920). Public health measures were beginning to lower death rates even among "backward" peoples (Ross, 1911: 109-110; Stoddard, 1920: 8). Continued high fertility increased population pressure and made these peoples migratory. Shades of both demographic transition theory and Kingsley Davis's multiphasic response theory are present in these early works.

17 Several such letters can be found in nearly every issue of the Birth Control Review.
In 1929 Sanger published Motherhood in Bondage, a compilation of the especially pathetic letters from the more than 50,000 she had received by that date.

18 When asked by Sanger to participate in the Sixth International Birth Control and Neo-Malthusian Conference, Davenport declined, saying that (quoted in Chase, 1977: 55): "the confusion of eugenics (which in its application to humans is qualitative) with birth control (which as set forth by most of its propagandists is quantitative) is, or was considerable, and the association of the director of the Eugenics Record Office with the Birth Control Conference would only serve to confuse the distinction. I trust, therefore, you will appreciate my reason for not wishing to appear as a supporter of the Birth Control League or of the conference."

19 Sanger's success at arranging conferences was due to her access to funds (she had many society contacts and her second husband was quite wealthy) and her great organizing ability. She was the instigating force behind the National Birth Control Conference (New York, 1921); the Sixth International Birth Control and Neo-Malthusian Conference (New York, 1925), and the World Population Conference (Geneva, 1927). The Geneva conference led to the founding of the International Union for the Scientific Investigation of Population Problems in 1928 (later to become the International Union for the Scientific Study of Population). Lorimer (1981: 488) contends that it was the IUSIPP's unwillingness to explicitly support the birth control movement that led to Sanger's and Fairchild's interest in establishing the PAA.

20 Frank Notestein (1981: 485) expressed such a suspicion when he discussed the groups represented at the founding session of the PAA: "Then there were the birth controllers who were willing to beat the drum with any stick that came handy, but the drum was the cause of women's right to control their reproductive destiny."

21 Edward Shils (1970: 763) defined this process: "By institutionalization of an intellectual activity I mean the relatively dense interaction of persons who perform that activity. ... The high degree of institution- 
alization of an intellectual activity entails its teaching and investigation within a regulated, scheduled, and systematically administered organization. . . It also entails the organized support of the activity from outside the particular institution and the reception or use of the results of the activity beyond the boundaries of the institution."

22 The Scripps Foundation for Research in Population Problems, established in 1922 , was located at Miami University (Ohio) and employed Warren Thompson and P. K. Whelpton, but offered no training. With a grant from the Milbank Memorial Fund, Princeton's Office of Population was established in 1936 and began to offer graduate training.

23 The interest of biologists in population studies during the first third of this century was closely linked to eugenics. Their central concem was the biological consequences of population trends. Other than Pearl's logistical curve theory of population growth (1925). little work was done on the determinants of population trends. Even Pearl eventually came to consider the increased practice of contraception, and not a biological mechanism triggered by increasing population density, the major reason for US fertility decline (1939: 246). As eugenics fell into scientific disrepute, most biologists withdrew from the eugenics movement and the field of human population studies.

24 Other works that also came close to being demography textbooks were Carroll Wright's Outline of Practical Sociology (1899), William Bailey's Modern Social Conditions (1906), and George Whipple's Vital Statistics (1919).

25 Willcox's first statistics course at Cornell, in 1891, was given under the guise of an Applied Ethics course. In 1892 Willcox became assistant professor of statistics and social science; he assumed a chair in political economy and statistics in 1901 (National Cyclopedia, 1930: 345-346; Notestein, 1968). Beginning in 1899, Willcox held key advisory positions for the Census Office. He influenced the development of demography both by producing model pieces of demographic research (1911. 1915, 1916a) and by finding employment in the field for many of its future luminaries (Anderson, 1988: 113).

26 Willcox quite consciously adopted this position, describing himself "not as an advocate but rather a judge who sums up the evidence . . . somewhat as the judge does before the jury" (quoted in Aldrich, 1979: 3).

27 The list of topics and speakers for the early PAA meetings illustrates the prevalence of biological Malthusianism among population scientists. The theme for the 1933 dinner meeting of the PAA, for instance, was "Who shall inherit America?" The topics presented were: "Is the quality of our population on the downgrade?"; "Which racial types will predominate in the future?"; "How will our cultural life change?": and "What will be the effect on business?" Roben Chaddock chaired the meeting, Frank Notestein and Frank Hankins were the speakers, and discussion was led by Frank Lorimer and Louis Dublin ( $\mathrm{Eu}$ genical News 28, no. 1: 64).

28 Anders Lunde (1981: 481) noted this distrust: "There was also an undercurrent of concern lest birth control advocates dominate the association." Clyde Kiser (1981: 494) observed: "It was for protection against the actionists in birth control, not the eugenists, that the original Association instituted a College of Fellows."

29 Lorimer (1981: 489) noted this contradiction: "The Association initially had a rather awkward institutional structure, with a select College of Fellows supposedly distinguished by their contributions to the advancement of knowledge; but all those who had been invited to attend the first conference were inscribed as charter members of the College-including both Mrs. Sanger and Mrs. Jones, who was president of the American Birth Control League at the time, and also Leon Whitney, a dog breeder. . . ."

30 Lorimer (1981: 488-489) criticizes Fairchild for being an advocate who "accorded high status in the Association's affairs to activists who lacked scientific qualifications." His advocacy was such that he overtly supported injustices so long as they furthered his cause (Fairchild, 1926: 129): "But bad means, contrary to many pious platitudes, not infrequently produce good results, and there 
can be no doubt that the policy of keeping this as far as possible a white man's country is fully justified in the event."

31 Thompson and Whelpton's Population Trends in the United States (1933) was published under the direction of President Herbert Hoover's Research Committee on Social Trends. The Committee on Population Problems of President Franklin Roosevelt's National Resource Committee produced The Problems of a Changing Population (Wilson et al., 1938) and Foundations of American Population Policy (Lorimer, Winston, and Kiser, 1940).
32 Early in the twentieth century the term "population quality" was used to allude to genetic capability or worth (see note 7). Today it has a broader meaning. Contemporary discussions of population quality are more likely to allude to such socioeconomic factors as education, occupation, and health status than to genetic worth. Modern demographers, then, might not appreciate the eugenic intent of those who committed their Association to ameliorate the "qualitative aspects" of population problems. Perhaps this explains the lack of any move within the PAA to recast the mission statement.

\section{References}

Aldrich, Mark. 1979. "Progressive economists and scientific racism: Walter Willcox and Black Americans," Phylon 40 (Spring): 1-14.

Allen, Nathan. 1882. "The New England family," New Englander 41, no. 145 (August): 137159.

— 1883. "Changes in New England population," The Popular Science Monthly 23 (August): 433-445.

Anderson, Margo. 1988. The American Census: A Social History. New Haven: Yale University Press.

Back, Kurt W. 1989. Family Planning and Population Control: The Challenges of a Successful Movement. Boston: Twayne Publishers.

Bailey, William. 1906. Modern Social Conditions. New York: The Century Co.

Bannister, Robert C. 1979. Social Darwinism: Science and Myth in Anglo-American Social Thought. Philadelphia: Temple University Press.

Bemis, Edward W. 1888. "Restriction of immigration," Andover Review 9 (March): 251-264. Bennett, David H. 1988. The Party of Fear: From Nativist Movements to the New Right in American History. Chapel Hill: University of North Carolina Press.

Billings, John. 1893. "The diminishing birth-rate in the United States," Forum 15 (June): 467477.

Boas, Franz. 1916. "Eugenics," Scientific Monthly 3: 471-478.

- 1925. "This Nordic nonsense," Forum 74 (October): 502-51 1.

Brigham, Carl C. 1923. A Study of American Intelligence. Princeton: Princeton University Press. . 1930. "Intelligence tests of immigrant groups," The Psychological Review 37 (September): 158-165.

Burch, Guy Irving. 1932. "Birth control vs. class suicide," Survey Graphic (April): 41, 64.

Bushee, Frederick A. 1903. "The declining birth-rate and its cause," Popular Science Monthly 63 (August): 355-361.

Cannon, Cornelia James. 1922. "American misgivings," Atlantic Monthly 129, no. 2 (February): 145-157.

Carey, Henry C. 1840. Principles of Political Economy, Vol. 3. Philadelphia: Carey, Lea and Blanchard.

Carr-Saunders, A. M. 1922. The Population Problem: A Study in Human Evolution. London: Oxford University Press.

Chase, Allan. 1977. The Legacy of Malthus: The Social Costs of the New Scientific Racism. New York: Knopf.

Clarke, R. F. 1896. "Neo-Malthusianism," North American Review 163 (September): 345-361. 
Commons, John R. 1904. "Amalgamation and assimilation," Chautauquan 39, no. 3 (May): 217-227.

- 1907. Races and Immigrants in America. New York: Chautauqua Press.

Coolidge, Calvin. 1921. "Whose country is this?" Good Housekeeping 72 (February): 13-14, $106,109$.

Davenport, Charles. 1920. "Heredity of constitutional mental disorders," Psychological Bulletin 17, no. 9 (September): 300-310.

Davids, Leo. 1968. "Franklin Henry Giddings: Overview of a forgotten pioneer," Journal of the History of the Behavioral Sciences 4, no. 1 (January): 62-72.

Dekker, H. C. 1918. "Overcrowding the world," Birth Control Review 2, no. 1 (January): 6, 11.

Demeny, Paul. 1988. "Social science and population policy," Population and Development Review 14, no. 3 (September): 451-479.

Dennett, Mary Ware. 1926. Birth Control Laws: Shall We Keep Them or Abolish Them? New York: Frederick H. Hitchcock (Grafton Press).

Dublin, Louis. 1918. "The significance of the declining birth rate," Science 47, no. 1209 (March): 201-210.

1920. "Birth control," Social Hygiene 6, no. I (January): 5-16.

. 1923. "The higher education of woman and race betterment," in Eugenics in Race and State, Vol. 2 (Proceedings of the Second International Congress of Eugenics). Baltimore: Williams and Wilkins Co., pp. 377-385.

. 1926a. "The statistician and the problem," in Population Problems in the United States and Canada, ed. Louis Dublin. New York: Houghton Mifflin Co., pp. 3-18.

— 1926b. "The fallacious propaganda for birth control," Atlantic Monthly 137, no. 2 (February): 186-194.

1966. After Eighty Years. Gainesville: University of Florida Press.

, and Alfred Lotka. 1925. "On the true rate of natural increase," Journal of the American Statistical Association 20, no. 150 (September): 305-339.

Durand, Edward Dana. 1916. "Some problems of population growth," Publications of the American Statistical Association 15, no. 114 (June): 129-148.

East, Edward M. 1923. "Civilization at the crossways," Birth Control Review 7, no. 12 (December): 328-332.

Emerick, Charles Franklin. 1909. "College women and race suicide," Political Science Quarterly 24, no. 2 (June): 269-283.

Fairchild, Henry Pratt. 1907. "Distribution of immigrants," Yale Review 16, no. 3 (November): 296-310.

- 1911. "The paradox of immigration," American Journal of Sociology 17, no. 2 (September): 254-267.

- 1912. "The restriction of immigration," American Economic Review 2, no. 1, Supplement (March): 53-62.

- 1926. The Melting Pot Mistake. Boston: Little, Brown and Company.

Farwell, Willard B. 1888. "Why the Chinese must be excluded," Forum 6 (October): 196203.

Fetter, Frank A. 1899. "Social progress and race degeneration," Forum 28 (October): 228238.

- 1913. "Population or prosperity," American Economic Review 3, no. 1, Supplement (March): 5-19.

Fisher, S. G. 1895. "Has immigration increased population?" Popular Science Monthly 48 (December): 244-255.

Franklin, Benjamin. 1961 [1751]. "Observations concerning the increase of mankind and the peopling of nations," in The Papers of Benjamin Franklin, Vol. 4, ed. Leonard W. Labaree. New Haven: Yale University Press, pp. 225-234.

Galton, Francis. 1869. Hereditary Genius: An Inquiry into Its Laws and Consequences. London: Macmillan and Co. 
1904. "Eugenics: Its definition, scope and aims," American Journal of Sociology 10, no. 1 (July): 1-25.

Garis, Roy L. 1926. "The necessity of excluding inferior stocks," Current History 24 (August): $666-671$.

- 1930. "Mexican invasion," Saturday Evening Post 202 (April): 43-44.

Goldenweiser, E. A. 1912. "Walker's theory of immigration," American Journal of Sociology 18, no. 3 (November): 342-351.

Gordon, Linda. 1977. "Birth control and the eugenists," Science for the People 9, no. 2: 8-15.

Gosney, Ezra S. 1931. "Sterilization and contraception," Birth Control Review 15, no. 7 (July): 202.

- and Paul Popenoe. 1929. Sterilization for Human Betterment: A Summary of Results of 6,000 Operations in California 1909-1929. New York: Macmillan Co.

Grant, Madison. 1916. The Passing of the Great Race. New York: Charles Scribner's Sons.

Hall, Prescott Farnsworth. 1904. "Selection of immigration," The Annals of the American Academy of Political and Social Science 19, no. 1 (July): 169-184.

Haller, Mark. 1963. Eugenics: Hereditarian Attitudes in American Thought. New Brunswick: Rutgers University Press.

Hankins, Franklin H. 1931. "The interdependence of eugenics and birth control," Birth Control Review 15, no. 6 (June): 170-171.

Harley, Louis R. 1895. "The doctrine of Malthus as it relates to modern society," American Magazine of Civics 6, no. I (January): 13-20.

Higham, John. 1963. Strangers in the Land: Patterns of American Nativism 1860-1925. New York: Atheneum.

-1984. Send These to Me: Immigrants in Urban America. Baltimore: Johns Hopkins University Press.

Hill, Joseph H. 1911. Fecundity of Immigrant Women, Vol. 28 of the Report of the Immigration Commission. Senate Documents, 6lst Congress, 2d Session, Vol. 65, pp. 731-826.

Hofstadter, Richard. 1945. Social Darwinism in American Thought 1860-1915. Philadelphia: University of Pennsylvania Press.

Hunter, Robert. 1904. Poverty. New York: Macmillan Co.

Hutchinson, Edward Prince. 1967. The Population Debate: The Development of Conflicting Theories Up to 1900. Boston: Houghton Mifflin.

Jennings, Herbert S. 1930. The Biological Basis of Human Nature. New York: W. W. Norton.

- 1931. "Eugenics," in Encyclopedia of the Social Sciences, Vol. 5, ed. Edwin Seligman and Alvin Johnson. New York: Macmillan Co., pp. 617-621.

Johnson, Roswell H. 1910. "The evolution of man and its control," Popular Science Monthly 76 (January): 49-70.

- 1922. "Eugenic aspect of birth control," Birth Control Review 6, no. 1 (January): 16.

Kennedy, David. 1970. Birth Control in America: The Career of Margaret Sanger. New Haven: Yale University Press.

Kevles, Daniel J. 1985. In the Name of Eugenics: Genetics and the Uses of Human Heredity. New York: Alfred A. Knopf.

Kiser, Clyde V. 1953. "The Population Association comes of age," Eugenical News 38 (December): 107-111.

- 1971. "The work of the Milbank Memorial Fund in population since 1928," Milbank Memorial Fund Quarterly 49, no. 4, part 2 (October): 15-62.

- 1981. "The role of the Milbank Memorial Fund in the early history of the Association," Population Index 47, no. 3: 490-494.

Knowlton, Charles. 1832. Fruits of Philosophy. New York: (no imprint).

Kosmak, George William. 1917. "Birth control: What shall be the attitude of the medical profession toward the present-day propaganda?" Medical Record 91 (February 17): 268273.

Laughlin, Harry H. (secretary). 1914. "I. The scope of the Committee's work" (Report of the "Committee to Study and to Report on the Best Practical Means of Cutting Off the 
Defective Germ-Plasm in the American Population," Bleeker Van Wagenen, Chairman), Bulletin No. 10A (February). Cold Spring Harbor, New York: Eugenics Record Office.

1922. Eugenical Sterilization in the United States. Chicago: Psychopathic Laboratory of the Municipal Court of Chicago.

Little, C. C. 1926. "Another view," Birth Control Review 10, no. 1 (January): 7, 34.

Lorimer, Frank. 1959. "The development of demography," in The Study of Population, ed. Philip H. Hauser and Otis Dudley Duncan. Chicago: University of Chicago Press, pp. 124-179. . 1981. "How demographers saved the Association," Population Index 47, no. 3: 488494.

, and Frederick Osborn. 1934. Dynamics of Population; Social and Biological Significance of Changing Birth Rates in the United States. New York: Macmillan.

, Ellen Winston, and Louise K. Kiser. 1940. Foundations of American Population Policy. New York: Harper and Brothers.

Ludmerer, Kenneth. 1972a. Genetics and American Society. Baltimore: Johns Hopkins University Press.

1972b. "Genetics, eugenics, and the Immigration Restriction Act of 1924," Bulletin of the History of Medicine 46 (January-February): 59-80.

Lundberg, George A. 1933. "Richmond Mayo-Smith," in Encyclopedia of the Social Sciences, Vol. 10, ed. Edwin Seligman and Alvin Johnson. New York: Macmillan Co., p. 237.

Lunde, Anders. 1981. "Population in the twenties and early thirties," Population Index 47, no. 3: $479-484$.

Martens, R. C. 1920. "The coming crash-America's prospect," Birth Control Review 4, no. 3 (March): 7-8.

Matthews, Fred H. 1977. Quest for an American Sociology: Robert E. Park and the Chicago School. Montreal: McGill-Queen's University Press.

Mayo-Smith, Richmond. 1888a. "Control of immigration I," Political Science Quarterly 3, no. 1 (March): 46-77.

. 1888b. "Control of immigration II," Political Science Quarterly 3, no. 2 (June): 197225.

. 1888c. "Control of immigration III," Political Science Quarterly 3, no. 3 (September): $409-424$.

1895. Statistics and Sociology. New York: Columbia University Press.

McDougall, William. 1921. Is America Safe for Democracy? New York: Charles Scribner's Sons. National Cyclopedia of American Biography, Vol. A. 1930. New York: James White and Company.

Nearing, Nellie Seeds. 1914. "Education and fecundity," Publications of the American Statistical Association 14, no. 106 (June): 156-174.

North, Simon Newton Dexter. 1918. "Seventy five years of progress in statistics: The outlook for the future," in The History of Statistics: Their Development and Progress in Many Countries, ed. John Koren. New York: Macmillan, pp. 15-52.

Notestein, Frank W. 1968. "Walter F. Willcox," in International Encyclopedia of the Social Sciences, Vol. 16, ed. David L. Sills. New York: Macmillan Co. and The Free Press, pp. 553-555. . 1971. "Reminiscences: The role of foundations, of the Population Association of America, Princeton University and the United Nations in fostering American interest in population problems," Milbank Memorial Fund Quarterly 49, no. 4, part 2 (October): 6784.

1981. "Memories of the early years of the Association," Population Index 47, no. 3: $484-488$.

. 1982. "Demography in the United States: A partial account of the development of the field," Population and Development Review 8, no. 4 (December): 651-687.

Osborn, Frederick. 1937. "Development of a eugenic philosophy," American Sociological Review 2, no. 3 (April): 389-397.

Owen, Robert Dale. 1831. Moral Physiology: or A Brief and Plain Treatise on the Population Question. New York: Wright and Owen. 
Park, Robert E., and Herbert A. Miller. 1921. Old World Traits Transplanted. New York: Harper and Brothers.

Pearl, Raymond. 1923. "Menace of population growth," Birth Control Review 7, no. 3 (March): 65-67.

- 1925. The Biology of Population Growth. New York: Alfred Knopf.

. 1927. "The biology of superiority," American Mercury 12, no. 47 (November): 257266.

1939. The Natural History of Population. London: Oxford University Press.

Pearson, Karl. 1901. National Life from the Standpoint of Science. London: A. and C. Black.

Phillips, John C. 1916. "A study of the birth rate in Harvard and Yale graduates," Harvard Graduates' Magazine 97 (September): 25-34.

Pickens, Donald K. 1968. Eugenics and the Progressives. Nashville: Vanderbilt University Press. Popenoe, Paul. 1917a. "Stanford's marriage-rate," Journal of Heredity 8, no. 4 (April): 170173.

. 1917b. "Birth control and eugenics," Birth Control Review 1, no. 3 (April-May): 6.

. 1928. "The number of persons needing sterilization," Journal of Heredity 19, no. 9 (September): 405-411.

- 1930. "The immigrant tide," in The Alien in Our Midst or "Selling Our Birthright for a Mess of Pottage": The Written Views of a Number of Americans (Present and Former) on Immigration and Its Results, ed. Madison Grant and Charles Davison. New York: The Galton Publishing Co., pp. 210-213.

Population Association of America Archives. 1931- Washington, D.C.: Georgetown University Library.

Reed, James. 1978. From Private Vice to Public Virtue: The Birth Control Movement and American Society Since 1830. New York: Basic Books.

Reuter, Edward Byron. 1923. Population Problems. Philadelphia: J. B. Lippincott Co.

Roosevelt, Theodore. 1897 [1894]. "National life and character," in Theodore Roosevelt, American Ideals and Other Essays, Political and Social. New York: G. P. Putnam's Sons, pp. $271-302$.

- 1907. "A letter from President Roosevelt on race suicide," The American Monthly Review of Reviews 35, no. 5 (May): 550-551.

Ross, Edward Alsworth. 1901. "The causes of race superiority." The Annals of the American Academy of Political and Social Science 18, no. 1 (July): 67-89.

- 1911. The Changing Chinese. New York: The Century Co.

1912. Changing America; Studies in Contemporary Society. New York: The Century Co. 1920. "The growth of population," Birth Control Review 4, no. 3 (March): 5-7, 1718.

1921. "The menace of migrating people," Century 102 (May): 131-134.

1927. Standing Room Only? New York: The Century Co.

Rossiter, William S. 1907. "Why we need the immigrant," The American Monthly Review of Reviews 35, no. 3 (March): 319-328.

- 1909a. "The significance of the decreasing proportion of children," The Annals of the American Academy of Political and Social Science 34, no. 1 (July): 71-80.

. 1909b. A Century of Population Growth. Washington, D.C.: US Government Printing Office.

Samelson, Franz. 1978. "From 'race psychology' to 'studies in prejudice': Some observations on the thematic reversal in social psychology," Journal of the History of the Behavioral Sciences 14, no. 3 (July): 265-278.

Sanger, Margaret. 1919. "Birth control and racial betterment," Birth Control Review 3, no. 2 (February): 11-12.

1920. "A birth strike to avert world famine," Birth Control Review 4, no. 1 (January): 3.

. 1925. "The need for birth control in America," in Birth Control: Facts and Responsibilities, ed. Adolf Meyer. Baltimore: The Williams and Wilkins Company, pp. 11-49. 
1926. "The function of sterilization," Birth Control Review 10, no. 10 (October): 299. 1929. Motherhood in Bondage. New York: Brentano's.

Satariano, William A. 1979. "Immigration and the popularization of social science," Journal of the History of the Behavioral Sciences 15, no. 3 (July): 310-320.

Seligman, Edwin R. 1901. "Richmond Mayo-Smith," Columbia University Quarterly 4 (December): 40-45.

Shils, Edward. 1970. "Tradition, ecology, and institution in the history of sociology," Daedalus 99, no. 4: 760-825.

Smith, A. Lapthorn. 1905. "Higher education of women and race suicide," Popular Science Monthly 66 (March): 466-473.

Solomon, Barbara Miller. 1956. Ancestors and Immigrants. Cambridge: Harvard University Press.

Soloway, Richard A. 1990. Demography and Degeneration: Eugenics and the Declining Birthrate in Twentieth-Century Britain. Chapel Hill: University of North Carolina Press.

Spencer, Herbert. 1852. "A theory of population, deduced from the general law of animal fertility," Westminster Review 1, no. 2 (April): 468-501.

Stoddard, (Theodore) Lothrop. 1920. The Rising Tide of Color Against White World Supremacy. New York: Charles Scribner's Sons.

1922. Revolt Against Civilization: The Menace of the Under Man. New York: Charles Scribner's Sons.

Thompson, Warren S. 1915. Population: A Study in Malthusianism. New York: Longmans, Green and Co.

. 1920. "Race suicide in the United States," American Journal of Physical Anthropology

3, no. I (January-March): 97-146.

. 1924. "Eugenics as viewed by a sociologist," Monthly Labor Review 18, no. 2 (February): 227-239.

- 1930. Population Problems. New York: McGraw-Hill.

, and P. K. Whelpton. 1933. Population Trends in the United States. New York: McGrawHill.

Tucker, George. 1822. "On the future destiny of the United States"; and "On the theory of Malthus," in Essays on Various Subjects of Taste, Morals, and National Policy, by a Citizen of Virginia. Georgetown, D.C.: Joseph Milligan [Jacob Gideon, printer], pp. 1-24 and pp. 305-336.

- 1843. The Progress of the United States in Population and Wealth in Fifty Years. Boston: Little, Brown.

Vance, Rupert B. 1959. "The development and status of American demography," in The Study of Population, ed. Philip H. Hauser and Otis Dudley Duncan. Chicago: University of Chicago Press, pp. 286-313.

Walker, Francis A. 1891. "Immigration and degradation," Forum 11 (August): 634-644.

- 1892. "Immigration," Yale Review 1, no. 2 (August): 125-145. 1896. "Restriction of immigration," Atlantic Monthly 77, no. 464 (June): 822-829.

Ward, Lester Frank. 1886. "Broadening the way to success," Forum 2 (December): 340-350. 1891. "The transmission of culture," Forum 11 (May): 312-319.

. 1907. "Social darwinism," American Journal of Sociology 12, no. 5 (March): 709-710.

. 1913. "Eugenics, euthenics and eudemics," American Journal of Sociology 18, no. 6 (May): 737-754.

Ward, Robert DeCourcy. 1904. "The restriction of immigration," North American Review 179 (August): 226-237.

Weismann, August. 1893. The Germ Plasm; A Theory of Heredity. New York: Charles Scribner's Sons.

Whelpton, P. K. 1928. "Population of the United States, 1925 to 1975," American Journal of Sociology 34, no. 2 (September): 253-270.

Whipple, George Chandler. 1919. Vital Statistics: An Introduction to the Science of Demography. New York: John Wiley and Sons. 
Willcox, Walter F. 1906. "The distribution of immigrants in the United States," Quarterly Journal of Economics 20 (August): 523-546.

. 1911. "The change in the proportion of children in the United States and in the birth rate in France during the nineteenth century," Publications of the American Statistical Association 12, no. 93 (March): 490-499.

. 1912. "Comments on Fairchild's paper, 'The restriction of immigration," American Economic Review 2, no. 1, Supplement (March): 66-71.

. 1913. "How may the demand for demographers and the supply of them in the United States be increased?" Transactions of the 15th International Congress on Hygiene and Demography, Washington, D.C., 1912. Washington, D.C.: Transactions, Vol. 6: 67-73.

. 1915. "The expansion of Europe in population," American Economic Review 5, no. 4 (December): 737-752.

. 1916a. "The nature and significance of the changes in the birth and death rates in recent years," Publications of the American Statistical Association 15, no. 113 (March): $1-15$.

__ 1916b. "Fewer births and deaths: What do they mean?" Journal of Heredity 7, no. 3 (March): 119-127.

- 1931. "Immigration into the United States," in International Migration, Vol. 2, ed. Walter F. Willcox. New York: National Bureau of Economic Research, pp. 85-122.

Wilson, Edwin B. (chairman), et al. 1938. The Problems of a Changing Population (Report of the Committee on Population Problems to the US National Resource Committee). Washington, D.C.: US Government Printing Office.

Wright, Carroll D. 1899. Outline of Practical Sociology. New York: Longmans, Green, and Co. 